\title{
The effects of rent control in Latin America: A century of regulations in Argentina
}

\author{
Alejandro D. Jacobo \\ IEF FCE, Universidad Nacional de Córdoba, Argentina \\ CICE (CIECS-CONICET), Córdoba, Argentina
}

Konstantin A. Kholodilin

DIW Berlin, Germany

NRU HSE, St. Petersburg, Russia

\begin{abstract}
Following World War I, rent control became a standard policy response to the housing shortage and the resulting rent increases. Typically, economists blame it for creating inefficiencies in the housing market and beyond. We investigate whether rental market regulations (including rent control, protection of tenants from eviction, and housing rationing) had any effects in a middle-income Latin American economy, such as Argentina. To answer this question, we take advantage of a wide range of housing market indicators and restrictive rental regulation indices covering almost one century. Using a standard OLS model and MARS, a non-linear estimation technique, we find that rental market regulations have exerted a statistically significant negative impact on the growth rates of the real housing rents. However, they were only effective for short periods following both World Wars, when regulations were novel and particularly strong.
\end{abstract}

Keywords Argentina; housing rents; rent control; rental market regulations. JEL Classification: C21, E31, R38.

\section{Working Paper no 2001 January, 2020}




\title{
The effects of rent control in Latin America: A century of regulations in Argentina*
}

\author{
Alejandro D. Jacobo ${ }^{\mathrm{a}, \mathrm{b}}$, Konstantin A. Kholodilin ${ }^{\mathrm{c}, \mathrm{d}}$ \\ ${ }^{a}$ IEF FCE, Universidad Nacional de Córdoba, Blvd. Enrique Barros s/n, 5000, Córdoba, Argentina \\ ${ }^{b}$ CICE (CIECS-CONICET), Av. Valparaíso s/n, 5000, Córdoba, Argentina \\ ${ }^{c}$ DIW Berlin, Mohrenstraße 58, 10117, Berlin, Germany \\ ${ }^{d}$ NRU HSE, Kantemirovskaya ul. 3, 194100, St. Petersburg, Russia
}

\begin{abstract}
Following World War I, rent control became a standard policy response to the housing shortage and the resulting rent increases. Typically, economists blame it for creating inefficiencies in the housing market and beyond. We investigate whether rental market regulations (including rent control, protection of tenants from eviction, and housing rationing) had any effects in a middle-income Latin American economy, such as Argentina. To answer this question, we take advantage of a wide range of housing market indicators and restrictive rental regulation indices covering almost one century. Using a standard OLS model and MARS, a non-linear estimation technique, we find that rental market regulations have exerted a statistically significant negative impact on the growth rates of the real housing rents. However, they were only effective for short periods following both World Wars, when regulations were novel and particularly strong.
\end{abstract}

Keywords: Argentina; housing rents; rent control; rental market regulations.

JEL codes: C21, E31, R38.

\footnotetext{
${ }^{*}$ The authors express their gratitude to Patricia León from the Tornquist Library at the Central Bank of Argentina for sharing historical data and documents. They also thank Claudia Palacios for her support in gathering the rent laws and decrees. Daniela Gonzalez provided excellent research assistance. Part of this research was carried out when Alejandro D. Jacobo visited the ICAE at Universidad Complutense de Madrid, Spain, in June 2019. A preliminary version of this paper was presented by the authors in a seminar of the IEF at Universidad Nacional de Córdoba, Argentina, in August 2019, and in workshop organized by the Macroeconomic department of DIW Berlin, in October 2019. The authors wish to thank the participants of both meetings for their valuable remarks. The usual disclaimer applies.
} 


\section{Contents}

1 Introduction 1

2 Data 23

2.1 Dependent variable . . . . . . . . . . . . . . . . . . . . . . 3

2.2 Control variables . . . . . . . . . . . . . . . . . . . . 5

2.3 Regulation indices . . . . . . . . . . . . . . . . . . . . 6

$\begin{array}{lll}3 & \text { Econometric methodology } & 7\end{array}$

4 Results $\quad 9$

$\begin{array}{llr}5 & \text { Conclusions } & 10\end{array}$

$\begin{array}{lr}\text { Literature } & 10\end{array}$ 


\section{List of Tables}

$1 \quad$ Literature on rent control effects . . . . . . . . . . . . . . . . . . . . . . . 14

2 Data definitions and sources . . . . . . . . . . . . . . . 15

3 Descriptive statistics of variables used in regressions . . . . . . . . . . . . . . . 19

4 Rental market legal acts . . . . . . . . . . . . . . . . . . . . . . 20

5 Results of augmented Dickey-Fuller stationarity tests . . . . . . . . . . . . 31

6 Estimation results of OLS model for real rent growth . . . . . . . . . . . . . . 32

\section{List of Figures}

1 Tenant rate in Argentina, 1947-2018 . . . . . . . . . . . . . . . 33

2 Dependent and control variables, $1910-2017$. . . . . . . . . . . . . . . 34

3 Rental market regulation indices in Argentina, 1910-2017 . . . . . . . . . . . . 35

4 Regulation effects on real rent growth . . . . . . . . . . . . . . . . . 36 


\section{Introduction}

Following World War I, rent control became a standard policy response to housing shortages and the resulting rent increases. Virtually all countries used such policies throughout 20th century. Typically, economists stigmatize it for creating inefficiencies in the housing market and beyond. In this study, we investigate whether it had any effects in Argentina, a middleincome Latin American country. To answer this question, we take advantage of a wide range of housing market indicators and restrictive rental regulation indices for Argentina covering more than 100 years. We find that rent control exerted a statistically significant impact on the performance of its housing market.

Since the turn of the 20th century, the phenomenon of urbanization in Latin America, in general, and Argentina, in particular, is perceived as rapidly increasing, given the high rates of population growth and rise of the industrial activity, which was almost non-existent before the First World War and notably expanded in, at that time, a purely agricultural economy. Since then, Argentina has experienced a continual housing shortage.

Its constant population growth and the migration of its farmers to urban areas, coupled with an inflow of immigrants to the major cities of Argentina, are all elements leading to ever increasing demand for housing with respect to its supply. This inevitably led to increases in rental prices. Since 1921, the government has reacted to these developments by introducing rent control policies, much like governments in many other countries. As a pendulum, phases of stronger regulations have been followed by those of the deregulation. In 2016, a draft of national law on rental prices (Proyecto de una Ley Nacional de Alquileres) was submitted, which is aimed at strengthening rental market regulations. ${ }^{2}$ Among other things, it provides for capping rent increases by an average growth rate of the consumer price index and the wage index as well as extending the minimum contract duration from two to three years. Thus, we might experience a new phase of increasing intensity of rental market regulations.

Although Argentina seems to be a country of homeowners, the housing rental market is becoming more and more important, as seen in Figure 1. The share of tenant households used to be very high $(62 \%)$ in 1947, then it declined until it reached its historic minimum in 2001

\footnotetext{
${ }^{2}$ Ley de alquileres y reforma del CC y CN; http://www.senado.gov.ar/parlamentario/parlamentaria/ 374144/downloadPdf.
} 
(about 11\%). Since 2001, tenant occupancy rates have steadily increased, attaining $17 \%$ in 2017. Similar evolution is observable in Buenos Aires, its largest city, where the rate went from $82 \%$ in 1947 to $21 \%$ in 1991 and back above $34 \%$ in 2018.

In Argentina, interventions in the housing market use rent control and other restrictive measures were only effective during two short periods, being rather ineffective the rest of the time. During Perón's first presidency, the real estate market was virtually paralyzed. This was a consequence of a 1943 law that froze rents and interrupted evictions. These norms, in force until the fall of Perón in 1955, produced a severe contraction in the supply of dwellings for rent, because the profit expectations of real-state investors abruptly declined. Moreover, when Perón took the reins for his second presidential term, the economic outlook was very poor.

Under the circumstances, where rents were frozen and evictions not permitted, the real amount paid by occupants shrank to almost nothing and the market for houses for rental purposes almost disappeared. In what remained from the formerly large rental market, various means of avoiding the regulations were invented. For example, in order to get a place to stay, tenants agreed with landlords to pay the property taxes in addition to the rent. The fiscal appetite of the different governments also did not contribute to the effectiveness of rent controls. In fact, as landlords must pay income tax on rents received, contracted rents do not reflect reality: tenants pay the sum listed in the contract plus an additional amount through previously agreed promissory notes. Additionally, rental contracts require stamp duties. In almost all cases, the contract is not stamped by the parties in order to avoid this tax or is marked by half of the amount as agreed upon between the landlord and the tenant. The lack of stamp duties payment does not make a contract null. In case of eviction, the only risk that the landlord is bearing is the necessity to pay the stamp duties plus a penalty fee, which turns out to be ridiculously small when inflation is high.

There is an extensive literature on the effects of rent control, as shown in Table 1. Most studies address the US experience: nine out of 14 listed in the table. The rest focus on European countries, mostly Scandinavian (Denmark and Sweden). The majority of studies (nine) work with microdata, typically at the private household level. The studies concentrate on topics like residential mobility, misallocation of housing, rents, and homelessness. Few consider the effects on residential construction (Sims, 2007). The statistical methodology covers a wide range of 
techniques varying from simple cross-sectional regressions through panel data models and nonlinear models such as proportional hazard model, duration model, and logit. To our knowledge, there are no studies using econometric tools to analyze the effects of governmental regulations on the Argentinian housing market.

The contribution of the paper is threefold. First, it concentrates on the impact of rent control in a middle-income Latin American country. Second, this is the first assessment of rental regulations for Argentina and the overall region. Third, it uses a novel database with long-term time series of the Argentinian housing market.

This paper is organized as follows. Section 2 describes the data, their sources and transformations. Section 3 presents the estimation methodology. Section 4 reports and discusses the estimation results. Finally, section 5 concludes.

\section{Data}

In this section, the sources, transformations and characteristics of data are described. The list of data with their sources are reported in Table 2. Below, we describe the data used in this study in more detail.

It is difficult to obtain overlapping time series for the variables under different base periods in Latin American countries over the long-run and Argentina is not an exception. It is typical that, once the base period is changed, the old time series (based on the previous base period) are discontinued and the new ones are not extended backward for a significant number of years. Frequently, a change in the base period usually reflects improvements in statistical procedures that began in Argentina during the 1960s when its statistical system started developing. This makes unclear whether the observed differences across base periods effectively reflect changes in the series or merely shows the peculiarities of statistical procedures. Regardless, we carefully describe the variables as shown in Table 2 and adopt the "second-best methodology" consisting in the simple "chaining" of the series as the only alternative available.

\subsection{Dependent variable}

As our dependent variable, we take the average monthly rent index of a room in the City of Buenos Aires for the period 1914-1934 published by the Departamento del Trabajo of the 
Ministerio del Interior through its statistics division. From 1934 to 1961, the numbers also come from a contemporary index considering the consumption of a $4 \times 4.5$ meters room by an unskilled worker's family type (parents and two children under 14 years old) living in the City of Buenos Aires. We take the data from publications of the former Dirección Nacional de Estadística y Censos (DNEC, hereafter). This office also provides information for the 19611976 period and the variable turns out to be the rent of a house (excluding electricity) according to a survey on the living conditions of a working family ("familia obrera") carried out in the capital of Argentina.

According to the official statistics that we follow, rent for 1977-1988 comes from the consumer price index and include housing expenses. The set of goods and services selected in the expenses are sanitary repairs, tiles, cement, bricks, wood, and paint. This group excludes other things (gas, the cost to refill a balloon of gas, kerosene, charcoal and electricity). The index considers the capital of Argentina. However, from March 1977 the index includes the capital of the country and 19 suburban communities. The information for the index comes from the Encuesta Permanente de Hogares (Permanent Household Survey) and the data are elaborated and published by the Instituto Nacional de Estadística y Censos (INDEC is the Spanish acronym for the National Institute for Statistic and Censuses). As for 1988-1999, the index measures the evolution of the monthly effectively rent paid by households, with expenses considered separately.

For 1999-2013, the survey of the rental prices is monthly and based on the division of the geographical area into work zones composed of the City of Buenos Aires and the Greater Buenos Aires.

Finally, for 2014-2017, data come from the Dirección General de Estadística y Censos of the City of Buenos Aires. The IPCBA (this is a Spanish acronym for Consumer Price Index of the City of Buenos Aires) contains the rent variable.

The time series of monthly rent coming from different sources are linked to obtain a series covering the period 1914-2017, which is the first attempt of this sort for Argentina. This nominal rent is deflated using the consumer price index. The growth rates of the resulting time series are displayed in Figure 2.

In order to account for the methodological differences across these seven periods, in all 
regressions below, six dummies are introduced, for 1914-1934, 1935-1960, 1961-1976, 19771988, 1989-1998, and 1999-2013, denoted as D_meth1,..,D_meth6.

\subsection{Control variables}

Interest rate. From 1914 to 2008, the series represents the interest rate for 30-days loans in domestic currency (peso) to first-line companies (prime rate). From 2009 on, it is the 30-days discount rate to promissory notes. Ferreres et al. (2005) provides information for the 1910-2004 period. The series is updated with information from the web page of the Banco Central de la República Argentina.

Gross Domestic Product. As usual, the series is the sum of good and services produced by the Argentine economy during a year. Ferreres et al. (2005) covers 1910-2004, while the national accounts compiled from INDEC allow us to properly update the series.

Consumer Price Index. The series is from Ferreres et al. (2005), who presents values up to 2004. However, to continue the series, we have to consider the government's intervention in the Argentine Statistics Bureau (INDEC) from 2007 through 2015. During these years, the government started reporting official statistics that were systematically below the unofficial ones. We follow Cavallo and Bertolotto (2016) to update the annual series.

Population. This variable indicates the projected population in thousands of persons. From 1910 to 2004 the data come from Ferreres et al. (2005), while the series up to 2017 are from Dirección General de Estadísticas y Censos de la Ciudad de Buenos Aires.

Building permits. This variable broadly corresponds to the number of building permits, i.e., the administrative procedures through which the authorization for the construction of a building is requested. Each building permit generally corresponds to a work, so this variable largely reflects the number of buildings authorized. The source is the Revista Económica from the Banco de la Nación Argentina for the 1926-1934 period. A special request by the authors was made to the Dirección General de Estadística y Censos of the City of Buenos Aires for 19341943 data. From 1944 to now, data proceed from the building series of the national statistical office of Argentina through its different names (Dirección, Nacional del Servicio Estadístico, Dirección Nacional de Investigación Estadística y Censos, Dirección Nacional de Estadística y Censos, and INDEC). Unfortunately, to our knowledge, information about building permits is not available prior to 1926. 
The evolution of control variables between 1910 and 2017 is shown in Figure 2.

\subsection{Regulation indices}

This study focuses on the effects of governmental policies. Therefore, we need measures of their intensity. For this purpose, we use the restrictive rental market regulations indices elaborated by Kholodilin (2018) and Weber (2017). These indices cover three types of regulations: rent control, tenure security, and housing rationing. All three indices vary between 0 and 1: the higher the index, the more intense the regulation. The indices are constructed for Argentina based on a thorough analysis of the corresponding legal acts. Table 4 summarizes all relevant laws underlying the rental market regulation indices utilized in this study. Figure 3 depicts the evolution of the three indices between 1910 and 2017, with shaded areas denoting both World Wars. For comparison purposes, it also shows the evolution of the indices for Latin America and the world.

Rent control index measures the intensity restrictions imposed on the level of rent and its rate of increase. The economists distinguish between first- and second-generation rent controls (Arnott, 1995). The first generation implies a rent freeze, when rents are fixed at some level. For instances, in Argentina rents were frozen three times: 1921-1924, 1943-1956, and 1965-1970, at the January 1, 1920 level, at the December 31, 1942 level, and at the previous contract level, respectively. Under the second-generation rent control, the rent level, as a rule, is not frozen; instead, the restrictions are imposed on the growth rate of rent, which is typically anchored to some measure reflecting the cost of living. In this way, lawmakers guarantee that the real rental revenues of the landlords are not eroded by inflation. In Argentina, in 1970, rent increases were capped by the rate of increase of the official index of living costs (indice de costo de vida). However, between 1987 and 2014, the rents were nominally frozen, for the government did not allow rent to be indexed by inflation in order to avoid an inflationary spiral.

The tenure security index reflects the degree of protection that tenants have from evictions by landlords. The main instruments of protection are 1) eviction protection during term or period; 2) eviction protection at the end of term or period; 3) imposition of a minimum duration of rental contracts; and 4) prohibition of short-term (less than one year) tenancies. Between 1921 and 1949, the first two tools were applied in Argentina: contracts could be automatically prolonged by tenants and landlords could only evict them, if they had justifiable reasons to 
do so. These reasons included: 1) non-payment of rent; 2) abusive use of the rented premises; 3) tenants initiating scandals (escándalo); 4) the owner needs the dwelling for himself and his family; or 5) the owner plans to rebuild the house, having low housing capacity, in order to create more dwellings, etc. In 1949-1957, the restriction on the minimum duration of rental contracts was added. In 1957, this requirement was abandoned. Finally, from 1976 on, the automatic prolongation of existing rental contracts was no longer provided to the tenants. However, during the term of those contracts, the tenants are still protected from eviction.

The housing rationing index measures the intensity of redistribution of the existing housing stock. In Argentina, between 1949 and 1965, three such policies were applied: 1) obligatory registration of vacant dwellings by landlords and subletting tenants within 15 days; 2) landlords are required to let their dwellings within 30 days; and 3) in the Federal Capital and National Territories, the authorities can requisition vacant dwellings.

All variables are tested for stationarity. The results of the augmented Dickey-Fuller unitroot tests are reported in Table 5. For the real interest rate (RIRate), the null hypothesis of unit-root (presence of random walk) can, in most cases, be rejected at conventional significance levels. Other variables become stationary after taking first differences. Only the growth rate of population (DLPop) appears to be non-stationary reflecting a secular decline in the speed of expansion of Argentina's population.

\section{Econometric methodology}

In order to investigate the potential impacts of rental regulations on the real growth rates of housing rents, we use different estimation approaches.

First, we take advantage of a simple ordinary least squares (OLS) model:

$$
y_{t}=\alpha+\rho y_{t-1}+\sum_{k=1}^{K} \beta_{k} x_{k, t-1}^{C}+\sum_{l=1}^{L} \gamma_{l} x_{l, t-1}^{R}+\varepsilon_{t}
$$

where $y_{t}$ is the growth rate of real rent in period $t ; x_{k t}^{C}$ is a $k$-th control variable; $x_{l t}^{R}$ is an $l$-th regulation index (our focus variable); $\varepsilon_{t}$ is the disturbance term; and $\alpha, \beta$ 's, $\gamma$ 's, and $\rho$ are parameters to be estimated. Note that explanatory indices are taken with a lag in order to avoid possible endogeneity. Here we use a dynamic model in order to account for the possibility 
of persistent rent growth.

Second, we employ a multivariate adaptive regression splines (MARS) algorithm. This is a non-parametric piecewise regression technique that was introduced by Friedman (1991). It is especially useful for identifying non-linearities in regression models. These are modeled using potentially different slopes for each predictor. Thus, unlike the linear regression, MARS does not assume that coefficients are stable across the entire range of each variable and instead uses splines in order to fit piecewise linear continuous functions. This is very useful when considering long-run economic processes, where policy responses may be subject to structural breaks. The main advantages of MARS compared to other non-linear models (e.g., polynomial models) are the simplicity of the resulting econometric model, its interpretability, and automatic model selection.

Here, we use matrix notation in order to formulate MARS. The dependent variable $Y=$ $\left(y_{1}, \ldots, y_{T}\right)^{\prime}$ is regressed upon a set of potential independent variables $X=\left(X_{1}, \ldots, X_{M}\right)$ with $X_{m}=\left(x_{m 1}, x_{m 2}, \ldots, x_{m T}\right)^{\prime}$, where $M=K+L$. In addition, the MARS uses the so-called basic functions $(\mathrm{BF})$ of the form $(x-c)_{+}=\max \{0, x-c\}$ and $(c-x)_{+}=\max \{0, c-x\}$, where the subscript "+" means that the function takes only the positive value or zero in case of negative difference. Such pairs of linear functions are called "hinge functions" and the constant $c$ denotes a knot, where the slope changes. The collection of all possible BFs, $\mathcal{C}$, is used to construct the following model:

$$
\mathcal{C}=\left\{(x-c)_{+},(c-x)_{+}\right\} \text {with } c \in\left\{x_{m}, x_{m 2}, \ldots, x_{m T}\right\} \text { and } m=1, \ldots, M
$$

Each function is piecewise linear with a knot $c$ at every $x_{m t}$, and, in case if all input values are distinct, there are $T M$ hinge functions, or equivalently $2 T M$ basic functions. The model-building strategy is similar to a classical forward stepwise regression using as inputs the functions from the set $\mathcal{C}$ and their products. The complete MARS model is formulated as:

$$
Y=\beta_{0}+\sum_{m=1}^{M} \beta_{m} h_{m}(X)+\epsilon
$$

where $h_{m}(X)$ is a BF; a product of two or more such functions, if interactions between variables are permitted; or the original predictor, if it exerts a linear impact on the dependent variable. 
Here, however, we do not consider possible interactions. The coefficients $\beta_{m}$ are estimated by minimizing the sum of squared (residual) errors (SSE), similar to a standard linear regression model.

\section{Results}

The OLS regression estimation results are shown in Table 6. Columns (1) and (2) report the results of two models estimated using OLS. Both models include all control variables. In addition, model (1) contains the Rental Market Regulation Index (RMRI) and housing rationing index, while model (2) contains rent laws, tenure security, and housing rationing indices. Given that RMRI is a simple average of rent laws and tenure security indices, we can only use it together with the housing rationing index in order to avoid multicollinearity. The standard errors are heteroskedasticity and autocorrelation consistent. ${ }^{3}$ The autoregressive term is only significant in model (2). However, it has a negative sign, indicating rather erratic fluctuations of real rent growth rates. The only control variable that is statistically significant is the real interest rate. None of the regulation indices are statistically significant.

Columns (3) and (4) report the same two models estimated using MARS. The non-linearity is only allowed for regulation indices. The autoregressive term is dropped from both nonlinear models. The models always include the real interest rate, which appears to exert a statistically significant negative impact on the growth of real rents. In model (3), in addition, the Rental Market Regulation Index is contained. It has a negative effect on real rents, when it exceeds 0.542 and no effect below this threshold, see Figure 4. Such regulation intensity is only achieved during two episodes: 1923-1925 and 1945-1957. This is the aftermath of both World Wars. The first period is consistent with the introduction of rent control; an innovation that probably tended to act as a surprise for the economy at that time and consequently exercised its effects. The second period coincides with the presidency of Perón when Argentina experienced a turbulent subordination of the economy to politics (a "hyper-politization of economic life", in terms of Gerchunoff and Díaz Alejandro 1989, p. 59). This subordinate position was one of the reasons for the economic enlargement of the public sector and the upsurge of controls,

\footnotetext{
${ }^{3}$ These are estimated using the $v c v H C$ function of the $\mathbf{R}$ package sandwich (MacKinnon and White, 1985).
} 
which clearly included rents. The aim and priority of the Perón's government was to rapidly modify income distribution to create an economic order capable of preserving the distributive model pursued. Thus, rental regulations seem to be effective only when they are a novelty or a very strong policy, as they were during these periods.

\section{Conclusions}

In this study, we analyze the effects of rental market regulations in Argentina on the growth of real housing rent. We find that these regulations did exert a statistically significant impact on rent dynamics. They appear to dampen real rent increases. However, these effects are observed during two short periods following both World Wars: 1923-1925 and 1945-1957. This means that rental market regulations are effective when both rent control and tenure security are novel or very strong. Here, however, we do not consider potential effects on other aspects of the housing market, such as residential construction, quality of housing, and homeownership rate. ${ }^{4}$ These effects can counteract the policy-driven declines in real rents making such interventions far from desirable as a tool of rendering the housing affordable.

Hence, the policy recommendation for the governments of middle-income Latin American countries would be to not rely on rent controls and too strong tenure security, since when they are strong, they generate various negative byproducts, while, when they are weak, they hardly slow rent increases.

\section{Literature}

Arnott, R. (1995). Time for revisionism on rent control? Journal of Economic Perspectives 9(1), $99-120$.

Ault, R. W., J. D. Jackson, and R. P. Saba (1994). The effect of long-term rent control on tenant mobility. Journal of Urban Economics 35(2), 140-158.

\footnotetext{
${ }^{4} \mathrm{As}$ seen in our literature review in Table 1 , rent control can lead to all sorts of undesirable effects. In addition, Kholodilin et al. (2018) show that rental regulations lead to higher homeownership rates in the long run, thus destroying the rental housing market.
} 
Autor, D. H., C. J. Palmer, and P. A. Pathak (2014). Housing market spillovers: Evidence from the end of rent control in Cambridge, Massachusetts. Journal of Political Economy 122(3), $661-717$.

Benítez, J. (2016). Buscar un techo. La problemática de los inquilinos y los alquileres en la Ciudad Autónoma de Buenos Aires. Colección es nuestra la ciudad 2, 5-8.

Bettendorf, L. and E. Buyst (1997). Rent control and virtual prices: A case study for interwar Belgium. The Journal of Economic History 57(3), 654-673.

Cavallo, A. and M. Bertolotto (2016). Serie completa de inflación de Argentina desde 1943 a 2016 (Filling the gap in Argentina's inflation data).

Cosacov, N. (2012). Alquileres e inquilinos en la Ciudad de Buenos Aires. Una radiografía. Buenos Aires: Laboratorio de Políticas Públicas.

Diamond, R., T. McQuade, and F. Qian (2019). The effects of rent control expansion on tenants, landlords, and inequality: Evidence from San Francisco. American Economic Review 109(9), $3365-94$.

Early, D. W. and E. O. Olsen (1998). Rent control and homelessness. Regional Science and Urban Economics 28(6), 797-816.

Ferreres, O. J. et al. (2005). Dos siglos de economía argentina (1810-2004): historia argentina en cifras. Fundación Norte y Sur.

Friedman, J. H. (1991). Multivariate adaptive regression splines. The annals of statistics 19(1), $1-67$.

Gerchunoff, P. and C. Díaz Alejandro (1989). Peronist economic policies, 1946-55. In G. di Tella and R. Dornbusch (Eds.), The Political Economy of Argentina, 1946-83, pp. 59-88. St Antony's/Macmillan Series. Palgrave Macmillan, London.

Glaeser, E. L. and E. F. Luttmer (2003). The misallocation of housing under rent control. The American Economic Review 93(4), 1027-1046. 
Grimes, P. W. and G. A. Chressanthis (1997). Assessing the effect of rent control on homelessness. Journal of Urban Economics 41(1), 23-37.

Kholodilin, K., S. Kohl, Y. Prozorova, and J. Licheron (2018). Social policy or crowding-out? tenant protection in comparative long-run perspective. Higher School of Economics Research Paper No. WP BRP.

Kholodilin, K. A. (2018). Measuring stick-style housing policies: A multi-country longitudinal database of governmental regulations. DIW Berlin Discussion Paper 1727.

Krol, R. and S. Svorny (2005). The effect of rent control on commute times. Journal of Urban Economics 58(3), 421-436.

MacKinnon, J. G. and H. White (1985). Some heteroskedasticity-consistent covariance matrix estimators with improved finite sample properties. Journal of econometrics 29(3), 305-325.

Moon, C.-G. and J. G. Stotsky (1993). The effect of rent control on housing quality change: a longitudinal analysis. Journal of Political Economy 101(6), 1114-1148.

Munch, J. R. and M. Svarer (2002). Rent control and tenancy duration. Journal of Urban Economics 52(3), 542-560.

Olsen, E. O. (1972). An econometric analysis of rent control. Journal of Political Economy $80(6), 1081-1100$.

Reese, E., F. Almansi, J. Del Valle, and J. Andrés (2014). Políticas habitacionales y la regulación del alquiler en Argentina. In A. G. Blanco, V. Fretes Cibils, and A. F. Muñoz (Eds.), Busco casa en arriendo: promover el alquiler tiene sentido, Chapter 4, pp. 93-132. Banco Interamericano de Desarrollo.

Sims, D. P. (2007). Out of control: What can we learn from the end of Massachusetts rent control? Journal of Urban Economics 61(1), 129-151.

Skak, M. and G. Bloze (2013). Rent control and misallocation. Urban Studies 50(10), 19882005. 
Svarer, M., M. Rosholm, and J. R. Munch (2005). Rent control and unemployment duration. Journal of Public Economics 89(11-12), 2165-2181.

Weber, J. P. (2017). The regulation of private tenancies - a multi-country analysis. PhD Dissertation, Universität Regensburg. Available at https://epub.uni-regensburg.de/ 36228/1/Weber $\% 20 \% 282017 \% 29$ _The $\% 20$ Regulation $\% 20$ of $\% 20$ Private $\% 20$ Tenancies $\% 20$ A 20Multi-Country\%20Analysis.pdf.

Wilhelmsson, M., R. Andersson, and K. Klingborg (2011). Rent control and vacancies in Sweden. International Journal of Housing Markets and Analysis 4(2), 105-129. 


\section{Appendix}

\section{Table 1: Literature on rent control effects}

\begin{tabular}{|c|c|c|c|c|}
\hline Study & Place and period & Type of data & Method & Effects \\
\hline Ault et al. (1994) & New York, 1968 & $\begin{array}{l}\text { micro, housing vacancy } \\
\text { survey }\end{array}$ & $\begin{array}{l}\text { cross- } \\
\text { sectional } \\
\text { regression }\end{array}$ & lower mobility \\
\hline Munch and Svarer (2002) & $\begin{array}{l}\text { Denmark, } 1992- \\
1999\end{array}$ & $\begin{array}{l}\text { micro, } 10 \% \text { random sample } \\
\text { of adult population }\end{array}$ & $\begin{array}{l}\text { proportional } \\
\text { hazard model }\end{array}$ & lower mobility \\
\hline Krol and Svorny (2005) & $\begin{array}{l}\text { New Jersey, } 1980 \text {, } \\
1990, \text { and } 2000\end{array}$ & census tract data & $\begin{array}{l}\text { cross- } \\
\text { sectional } \\
\text { regression }\end{array}$ & higher commute times \\
\hline Bettendorf and Buyst (1997) & $\begin{array}{l}\text { Belgium, } 1920- \\
1939\end{array}$ & macro & $\begin{array}{l}\text { Rotterdam } \\
\text { demand } \\
\text { model }\end{array}$ & $\begin{array}{l}\text { redistribution of household expenditure toward } \\
\text { non-housing consumption }\end{array}$ \\
\hline Sims (2007) & $\begin{array}{l}\text { Massachusetts, } \\
1985-1998\end{array}$ & micro, housing survey & & $\begin{array}{l}\text { little effect on new housing construction, shift } \\
\text { units away from rental status, and lower rents }\end{array}$ \\
\hline Glaeser and Luttmer (2003) & $\begin{array}{l}\text { New York City, } \\
1993\end{array}$ & micro, housing surveys & $\begin{array}{l}\text { cross- } \\
\text { sectional } \\
\text { regression }\end{array}$ & misallocation of housing \\
\hline Autor et al. (2014) & $\begin{array}{l}\text { Cambridge (Mas- } \\
\text { sachusetts), } 1995\end{array}$ & micro, parcels of land & $\begin{array}{l}\text { cross- } \\
\text { sectional } \\
\text { regression }\end{array}$ & $\begin{array}{l}\text { large and significant positive indirect effect of de- } \\
\text { control on the valuation of properties that were } \\
\text { exposed to controlled units }\end{array}$ \\
\hline Moon and Stotsky (1993) & $\begin{array}{l}\text { New York, } 1978- \\
1987\end{array}$ & micro, housing units & $\begin{array}{lr}\text { Tobit and } \\
\text { panel data } \\
\text { model }\end{array}$ & $\begin{array}{l}\text { decline in the quality of rent-controlled dwellings } \\
\text { or reduction of the chances that housing units } \\
\text { improve in quality }\end{array}$ \\
\hline $\begin{array}{l}\text { Grimes and Chressanthis } \\
(1997)\end{array}$ & $\begin{array}{l}200 \text { US cities, } \\
1990\end{array}$ & macro, census data & TSLS & higher homelessness \\
\hline Early and Olsen (1998) & $\begin{array}{l}44 \text { US metropoli- } \\
\tan \text { areas, } 1985- \\
1988\end{array}$ & $\begin{array}{l}\text { macro, housing survey and } \\
\text { micro, homelessness sur- } \\
\text { vey }\end{array}$ & $\begin{array}{l}\text { TSLS and } \\
\text { logit }\end{array}$ & net effect: lower homelessness \\
\hline Olsen (1972) & New York, 1968 & $\begin{array}{l}\text { micro, survey of housing } \\
\text { units }\end{array}$ & $\begin{array}{l}\text { cross- } \\
\text { sectional } \\
\text { regression }\end{array}$ & $\begin{array}{l}\text { increase of cost of landlords is larger than in- } \\
\text { crease of real income of households in controlled } \\
\text { units, hence, negative net cost for society }\end{array}$ \\
\hline Svarer et al. (2005) & $\begin{array}{l}\text { Denmark, } 1997- \\
2000\end{array}$ & $\begin{array}{l}\text { micro, } 10 \% \text { sample of adult } \\
\text { population }\end{array}$ & $\begin{array}{l}\text { competing } \\
\text { risks dura- } \\
\text { tion model }\end{array}$ & $\begin{array}{l}\text { individuals occupying controlled units are less } \\
\text { (more) likely to accept jobs outside (in) their } \\
\text { local market labor, hence, longer unemployment } \\
\text { duration }\end{array}$ \\
\hline Skak and Bloze (2013) & Denmark, 2004 & $\begin{array}{l}\text { micro, } 20 \% \text { sample of the } \\
\text { rental market }\end{array}$ & $\begin{array}{l}\text { hedonic } \\
\text { regression }\end{array}$ & $\begin{array}{l}\text { significantly lower rents in the controlled sectors } \\
\text { and to a negligible increase in the uncontrolled } \\
\text { rent }\end{array}$ \\
\hline Wilhelmsson et al. (2011) & $\begin{array}{l}\text { Sweden, } \quad 1994- \\
2004\end{array}$ & macro, municipalities & $\begin{array}{l}\text { panel data } \\
\text { model }\end{array}$ & lower vacancy rates \\
\hline Diamond et al. (2019) & $\begin{array}{l}\text { San Francisco, } \\
\text { 1990-2016 }\end{array}$ & $\begin{array}{l}\text { micro, address history of } \\
\text { individuals }\end{array}$ & $\begin{array}{l}\text { difference-in- } \\
\text { differences }\end{array}$ & $\begin{array}{l}\text { decreased mobility of tenants in controlled } \\
\text { dwellings; conversion of rental dwellings to con- } \\
\text { dos }\end{array}$ \\
\hline
\end{tabular}




\section{Table 2: Data definitions and sources}

\begin{tabular}{|c|c|c|c|}
\hline Variable & Period & Description & Source \\
\hline Rent & $1914-1934$ & $\begin{array}{l}\text { Average monthly rent of a room in the } \\
\text { city of Buenos Aires }\end{array}$ & $\begin{array}{l}\text { Ministerio del Interior (1949), Investi- } \\
\text { gaciones Sociales }\end{array}$ \\
\hline Rent & 1934-1956 & $\begin{array}{l}\text { An unskilled worker's family type (par- } \\
\text { ents and two children under } 14 \text { years } \\
\text { old) in the city of Buenos Aires con- } \\
\text { suming a } 4 \times 4,5 \mathrm{~m}^{2} \text { room }\end{array}$ & $\begin{array}{l}\text { Dirección Nacional de Estadística y } \\
\text { Censos (1957), Índices del costo del } \\
\text { nivel de vida, actividad industrial y } \\
\text { costo de la construcción }\end{array}$ \\
\hline Rent & $1956-1961$ & & $\begin{array}{l}\text { Dirección Nacional de Estadística y } \\
\text { Censos, Boletín Mensual de Estadística } \\
\text { de la República Argentina, various is- } \\
\text { sues }\end{array}$ \\
\hline Rent & $1961-1976$ & $\begin{array}{l}\text { Considers the rent of a house, exclud- } \\
\text { ing electricity, according to the survey } \\
\text { on living conditions of a working family } \\
\text { ("familia obrera") }\end{array}$ & $\begin{array}{l}\text { Dirección Nacional de Estadística y } \\
\text { Censos, Boletín Mensual de Estadística } \\
\text { de la República Argentina and Boletín } \\
\text { Estadístico Trimestral, various issues }\end{array}$ \\
\hline Rent & $1977-1984$ & $\begin{array}{l}\text { Rent considers the expenses for hous- } \\
\text { ing. The set of goods and services se- } \\
\text { lected in housing expenses are: rent, } \\
\text { sand, sanitary fixtures, tiles, cement, } \\
\text { bricks, wood, and paint. This group } \\
\text { does not include fuel (gas, the cost to } \\
\text { refill a balloon of gas, kerosene, char- } \\
\text { coal) and electricity }\end{array}$ & $\begin{array}{l}\text { Instituto Nacional de Estadística y } \\
\text { Censos. Fascículo Índice de precios al } \\
\text { consumidor y Salarios industriales, var- } \\
\text { ious issues }\end{array}$ \\
\hline Rent & 1985-1988 & & $\begin{array}{l}\text { Instituto Nacional de Estadística y } \\
\text { Censos, Estadística Mensual, various is- } \\
\text { sues }\end{array}$ \\
\hline
\end{tabular}




\begin{tabular}{|c|c|c|c|}
\hline Variable & Period & Description & Source \\
\hline Rent & 1989-1995 & $\begin{array}{l}\text { Measures the evolution of the monthly } \\
\text { effectively rent paid by households that } \\
\text { live in rented homes. The rental service } \\
\text { covers the accommodation, excluding } \\
\text { the payment of services (electricity, gas, } \\
\text { water, heating, use of the telephone). } \\
\text { It does not include: repair and main- } \\
\text { tenance of the dwelling (materials and } \\
\text { labor), electricity, sanitary services, gas } \\
\text { and other fuels }\end{array}$ & $\begin{array}{l}\text { Instituto Nacional de Estadística y } \\
\text { Censos Estadística Mensual, various is- } \\
\text { sues }\end{array}$ \\
\hline Rent & 1996-1999 & & $\begin{array}{l}\text { Instituto Nacional de Estadística y } \\
\text { Censos, Indec Informa, various issues }\end{array}$ \\
\hline Rent & 1999-2008 & $\begin{array}{l}\text { Rent, excluding fuels for housing, elec- } \\
\text { tricity, water and sanitary services, ma- } \\
\text { terials, as well as work for repairs and } \\
\text { common expenses of the home }\end{array}$ & $\begin{array}{l}\text { Instituto Nacional de Estadística y } \\
\text { Censos. Indec Informa, various issues }\end{array}$ \\
\hline Rent & 2008-2013 & $\begin{array}{l}\text { Rental of housing excludes: basic ser- } \\
\text { vices and fuel for housing (gas in carafe, } \\
\text { natural gas by network, kerosene); elec- } \\
\text { tricity; water and sanitary services } \\
\text { (sewers, and storm drains); materials } \\
\text { for repairs; common expenses of hous- } \\
\text { ing (expense) }\end{array}$ & $\begin{array}{l}\text { Instituto Nacional de Estadística y } \\
\text { Censos. Indec Informa, various issue }\end{array}$ \\
\hline Rent & $2014-2017$ & $\begin{array}{l}\text { Rental of the house, excluding mate- } \\
\text { rials for the repair of the house (pre- } \\
\text { mixed plaster, faucet set, ceramic floor, } \\
\text { and interior paint), services for the re- } \\
\text { pair of the house (locksmith, gas electri- } \\
\text { cian, painter, plumber), running water } \\
\text { supply, common expenses for housing } \\
\text { (expense), electricity and gas (packag- } \\
\text { ing and network). }\end{array}$ & $\begin{array}{l}\text { Dirección General de Estadística y } \\
\text { Censos de la Ciudad de Buenos Aires: } \\
\text { https://www.estadisticaciudad. } \\
\text { gob.ar/eyc/?p=28446 }\end{array}$ \\
\hline
\end{tabular}




\begin{tabular}{|c|c|c|c|}
\hline Variable & Period & Description & Source \\
\hline $\begin{array}{l}\text { Building per- } \\
\text { mits }\end{array}$ & $1926-1934$ & $\begin{array}{l}\text { Number of administrative procedures } \\
\text { through which the authorization for } \\
\text { the construction of the building is re- } \\
\text { quested. This variable largely reflects } \\
\text { the amount of works that are autho- } \\
\text { rized }\end{array}$ & $\begin{array}{l}\text { Banco de la Nación Argentina (1934), } \\
\text { Revista Económica }\end{array}$ \\
\hline $\begin{array}{l}\text { Building per- } \\
\text { mits }\end{array}$ & $1934-1943$ & & $\begin{array}{l}\text { Available upon request from Dirección } \\
\text { General de Estadística y Censos de la } \\
\text { Ciudad de Buenos Aires }\end{array}$ \\
\hline $\begin{array}{l}\text { Building per- } \\
\text { mits }\end{array}$ & $1943-2017$ & & $\begin{array}{l}\text { Dirección Nacional del Servicio Es- } \\
\text { tadístico, Anuario estadístico de la } \\
\text { República Argentina, Tomo I, Com- } \\
\text { pendio 1949-1950; Dirección Nacional } \\
\text { de Investigaciones, Estadística y Cen- } \\
\text { sos, Sintesis Estadística Mensual de } \\
\text { la República Argentina, various issues; } \\
\text { Dirección Nacional de Estadística y } \\
\text { Censo, Boletín Mensual de Estadística } \\
\text { de la República Argentina, various is- } \\
\text { sues; Dirección Nacional de Estadística } \\
\text { y Censos, Boletín de Estadística, var- } \\
\text { ious issues; Instituto Nacional de Es- } \\
\text { tadística y Censos, Boletín Estadístico } \\
\text { Trimestral, Edificación, Permisos para } \\
\text { Construcciones Privadas and Indec In- } \\
\text { forma, various issues }\end{array}$ \\
\hline $\begin{array}{l}\text { Consumer } \\
\text { price index }\end{array}$ & $1910-2004$ & $\begin{array}{l}\text { Measures the variations in prices in Ar- } \\
\text { gentina }\end{array}$ & Ferreres et al. (2005) \\
\hline $\begin{array}{l}\text { Consumer } \\
\text { price index }\end{array}$ & $2005-2017$ & & $\begin{array}{l}\text { Cavallo and Bertolotto (2016), } \\
\text { https://dx.doi.org/10.2139/ } \\
\text { ssrn.2787276 }\end{array}$ \\
\hline
\end{tabular}




\begin{tabular}{|c|c|c|c|}
\hline Variable & Period & Description & Source \\
\hline Interest rate & $1914-2004$ & $\begin{array}{l}\text { From } 1914 \text { to } 2008 \text { is the rate for } 30 \\
\text { days loans to first line companies. From } \\
2009 \text { onward, it is the interest rate of } \\
\text { discounted promissory notes }\end{array}$ & Dos siglos de Economía Argentina \\
\hline Interest rate & $2005-2017$ & & $\begin{array}{l}\text { Banco Central de la República Ar- } \\
\text { gentina: www.bcra.gob.ar }\end{array}$ \\
\hline GDP & $1910-2004$ & Gross Domestic Product of Argentina & Ferreres et al. (2005) \\
\hline GDP & $2004-2017$ & & $\begin{array}{l}\text { Instituto Nacional de Estadística y } \\
\text { Censos. Cuentas nacionales }\end{array}$ \\
\hline Births & $1910-2004$ & $\begin{array}{l}\text { Number of biths registered in Argentina } \\
\text { (whole country) }\end{array}$ & Ferreres et al. (2005) \\
\hline Births & $2004-2016$ & & $\begin{array}{l}\text { Dirección de Estadísticas e Informa- } \\
\text { ción de Salud. Estadisticas Vitales: } \\
\text { http://www.deis.msal.gov.ar/ } \\
\text { index.php/estadisticas-vitales/ }\end{array}$ \\
\hline
\end{tabular}




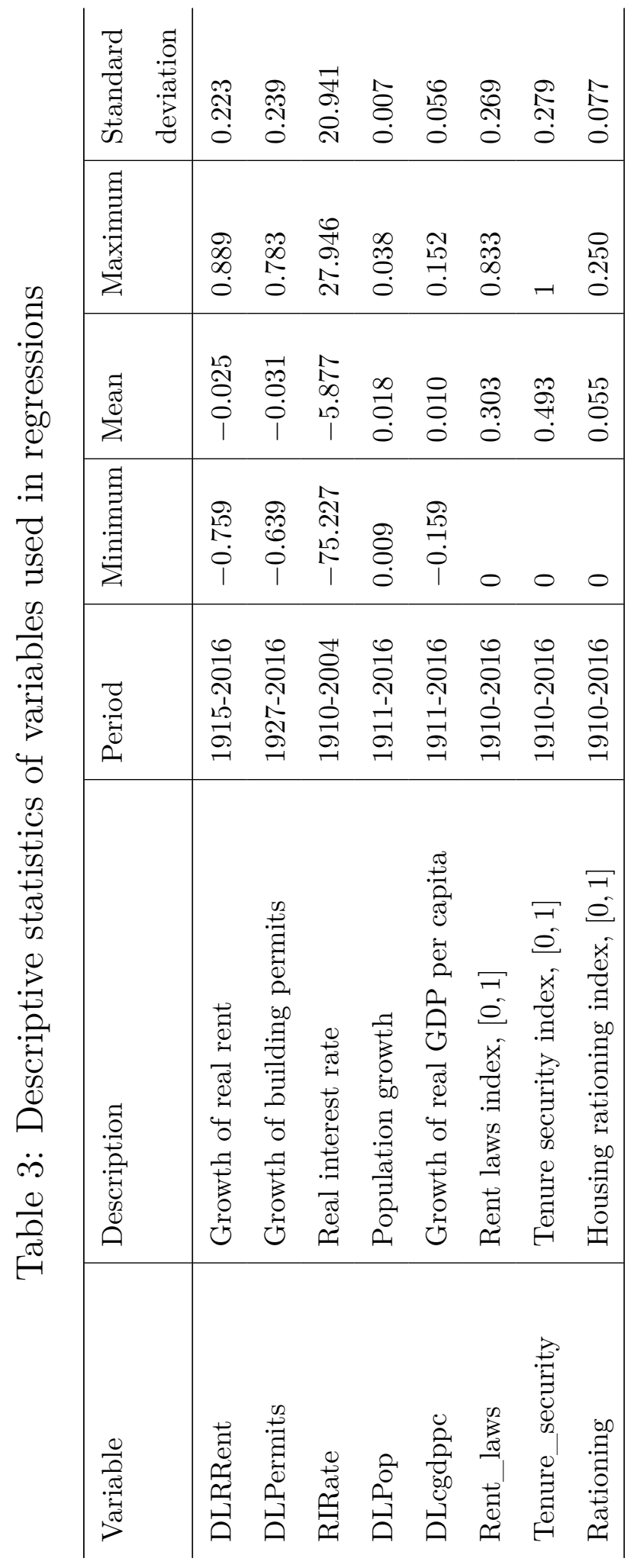




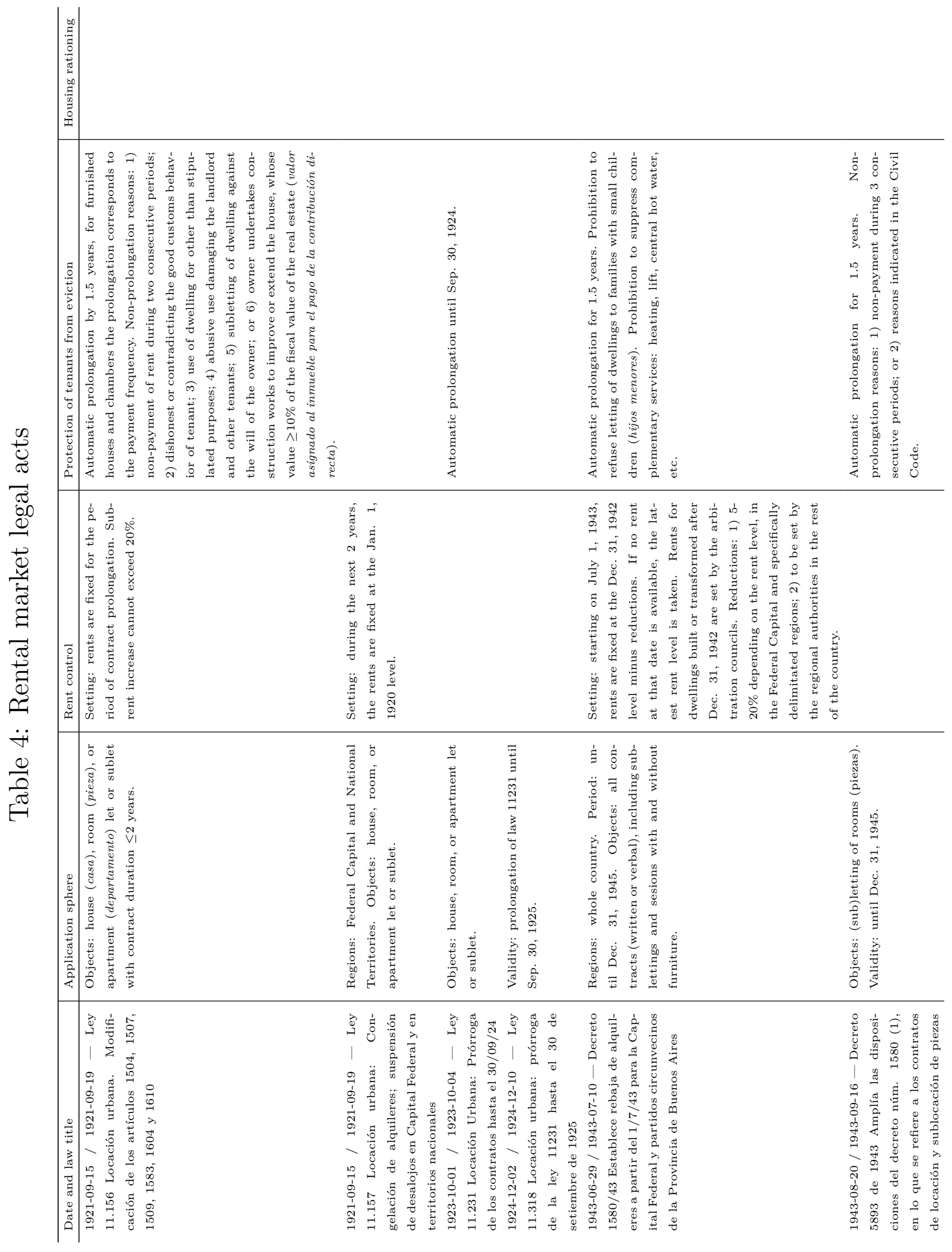




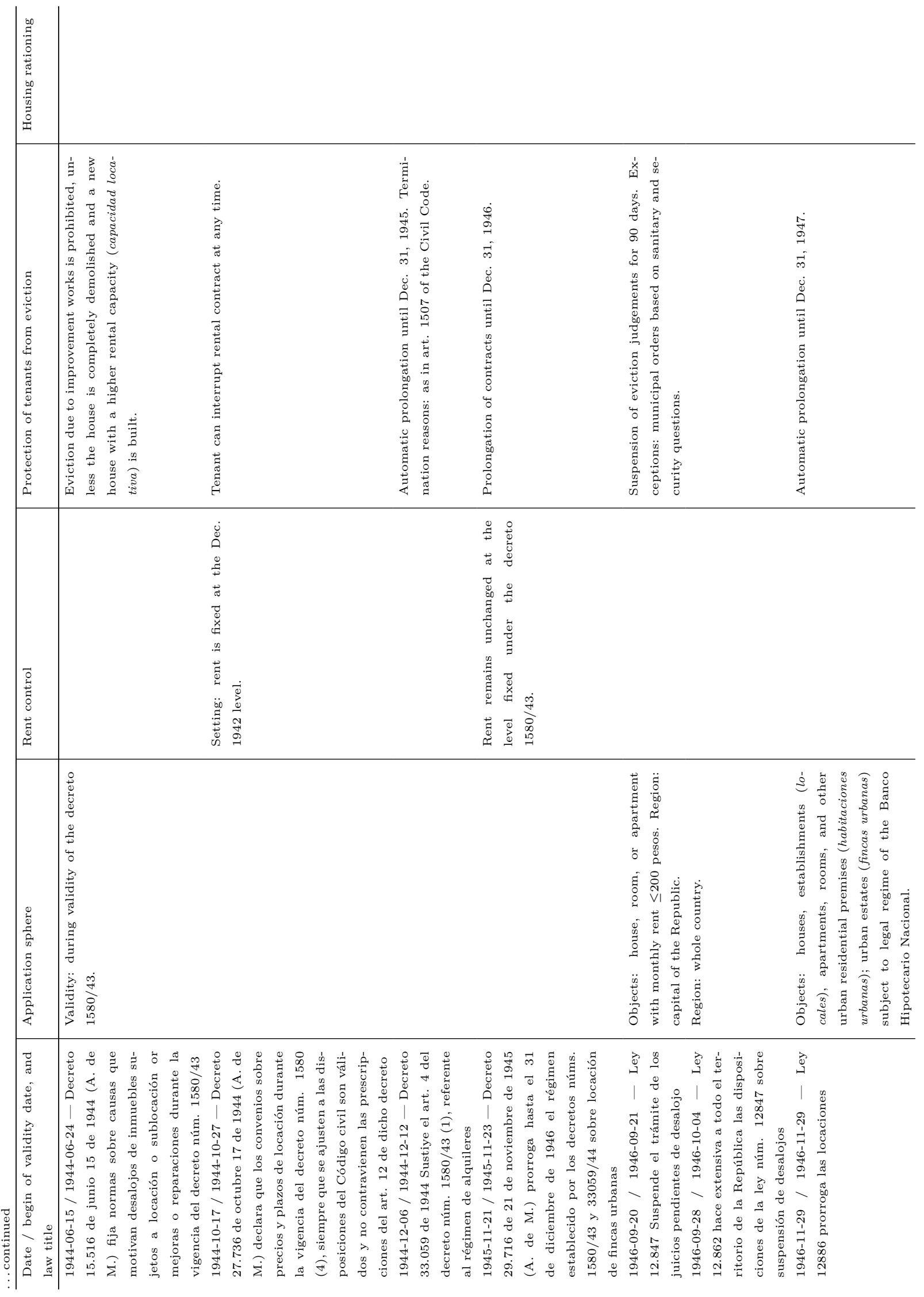




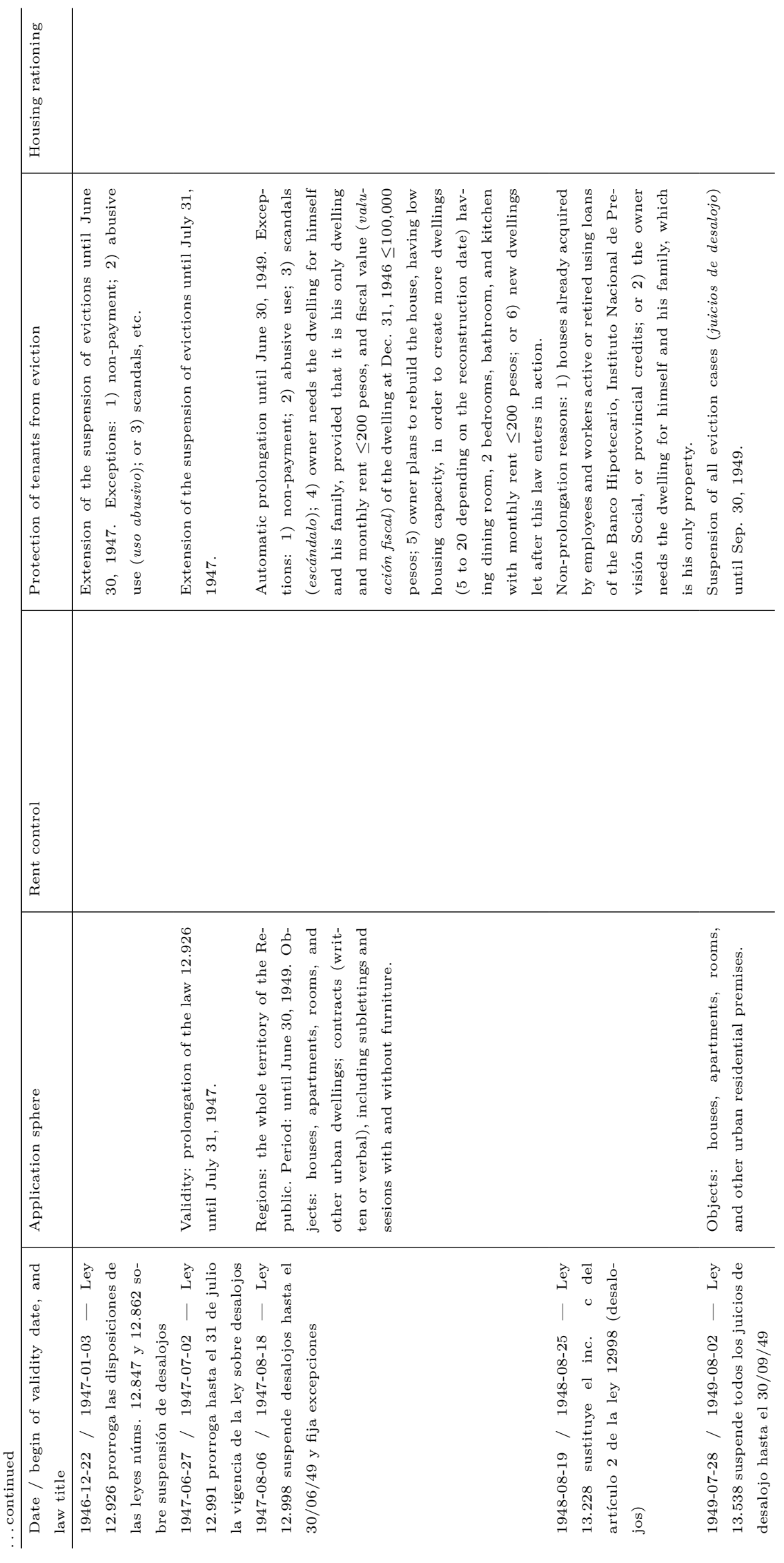




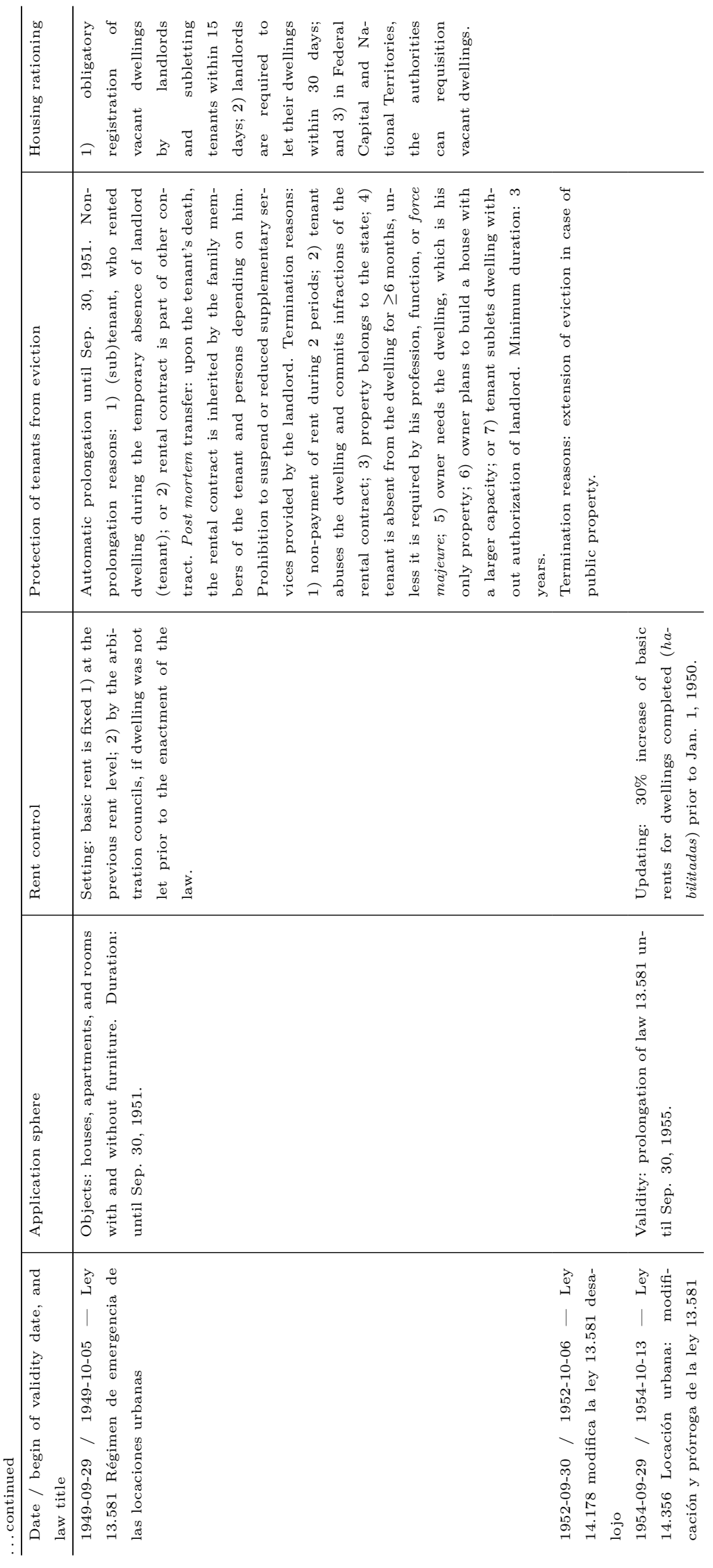




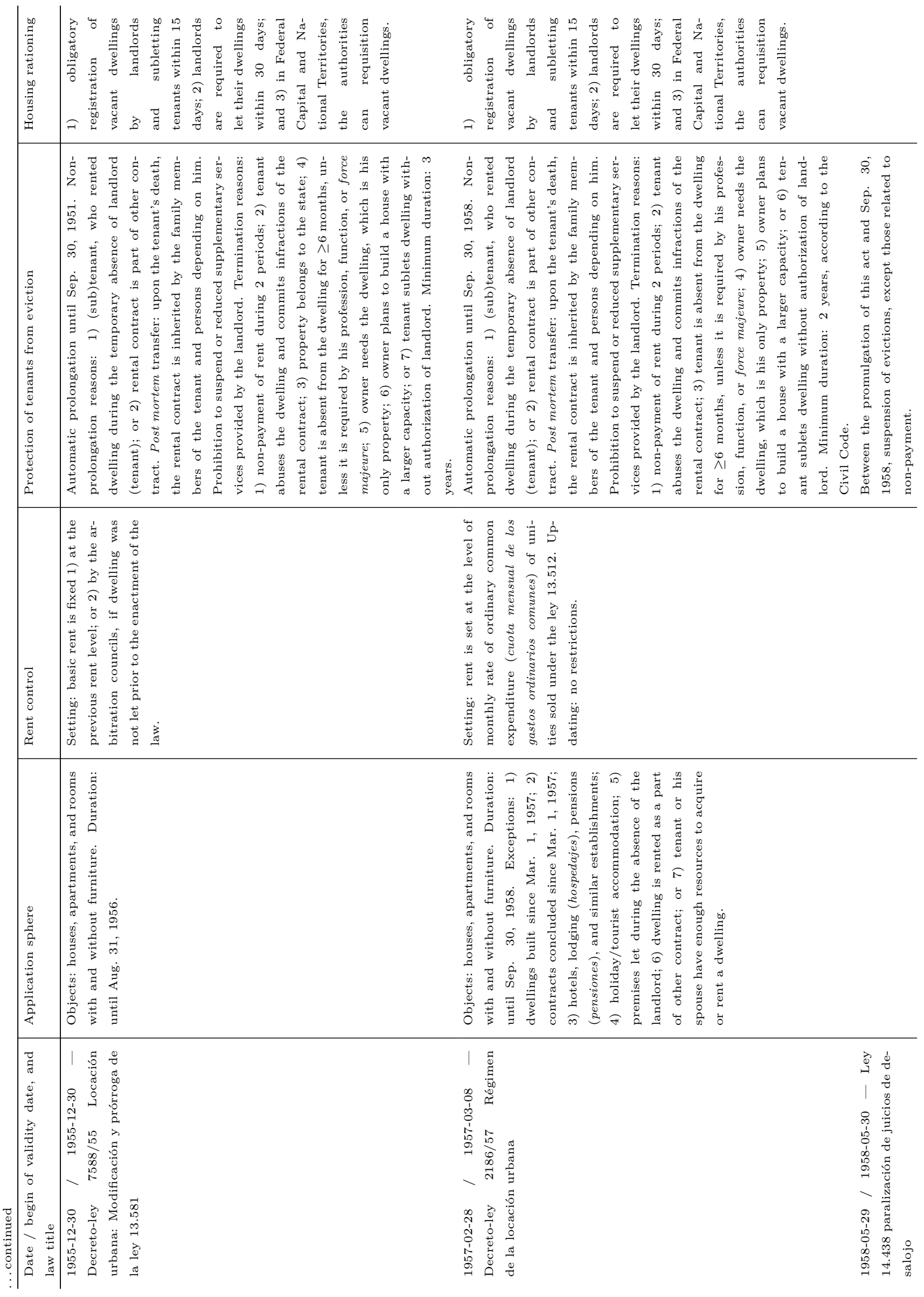




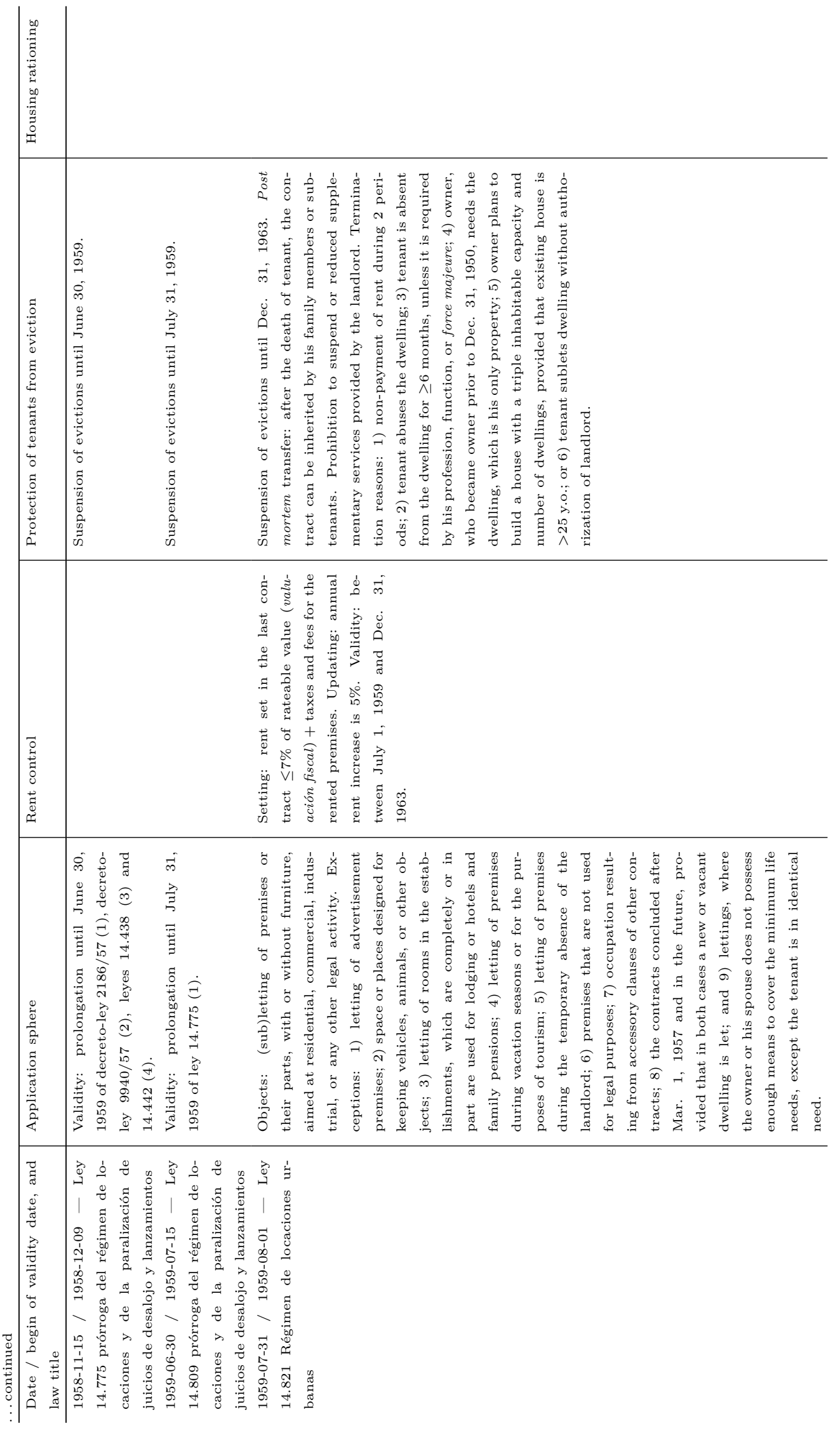




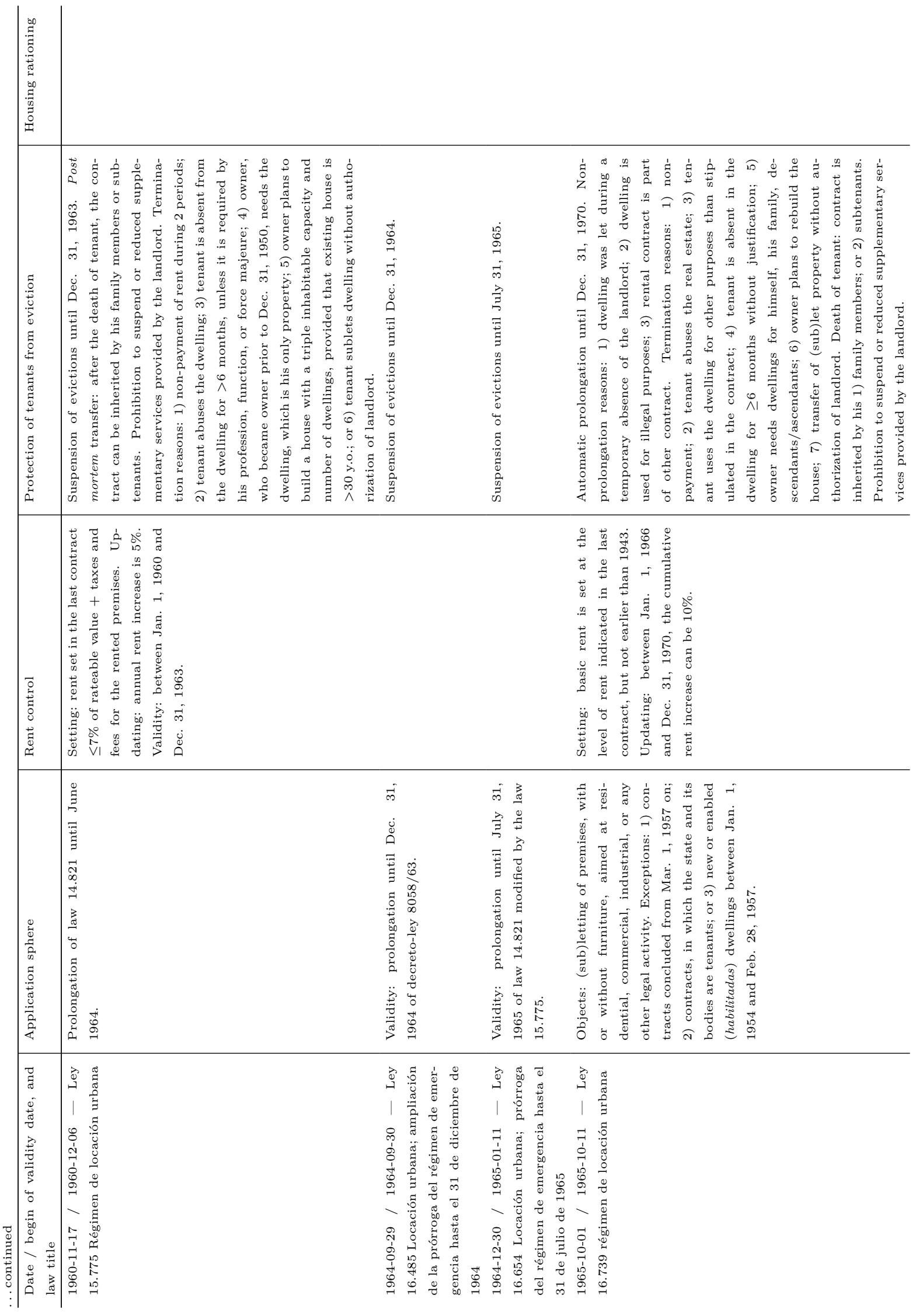




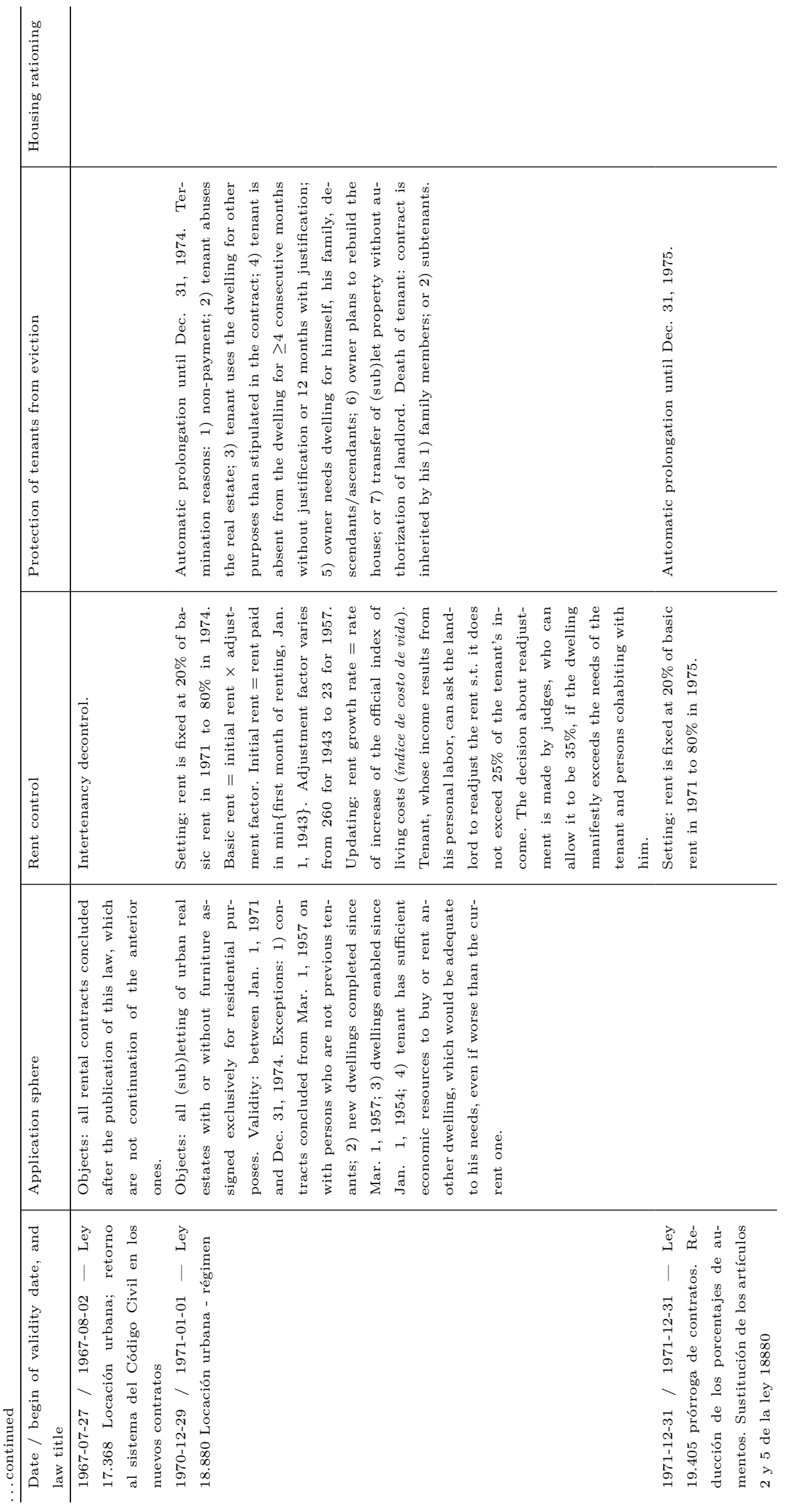




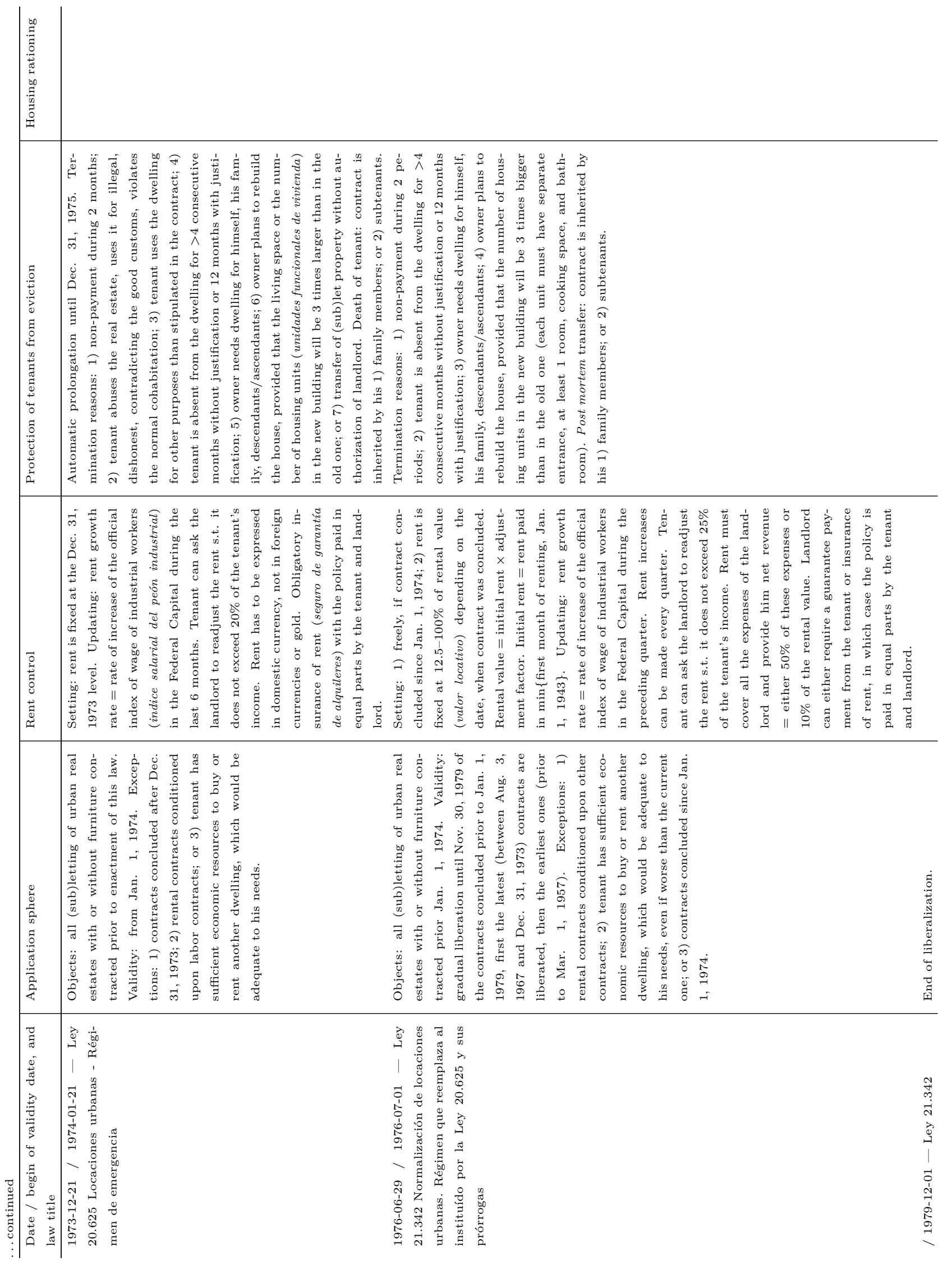




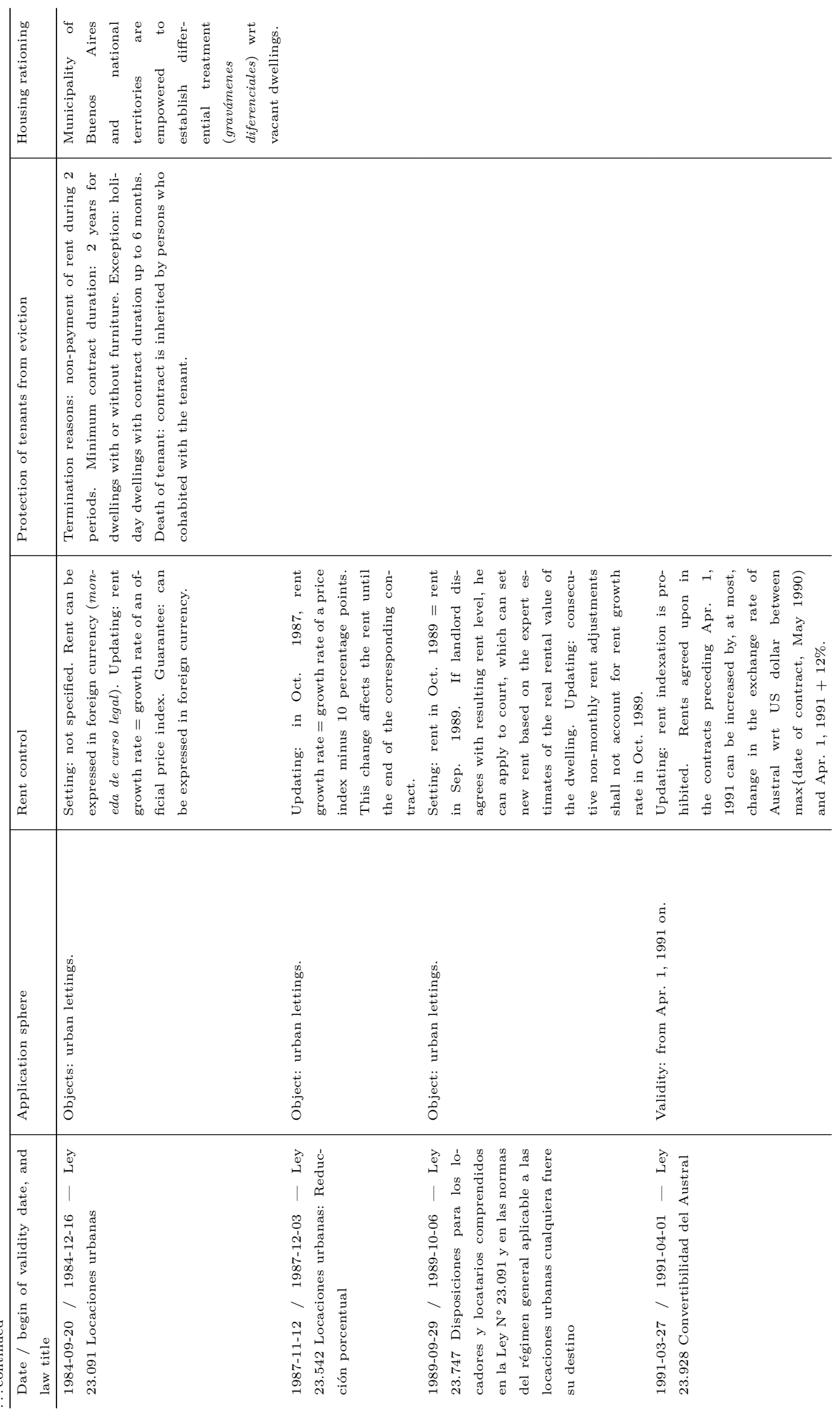




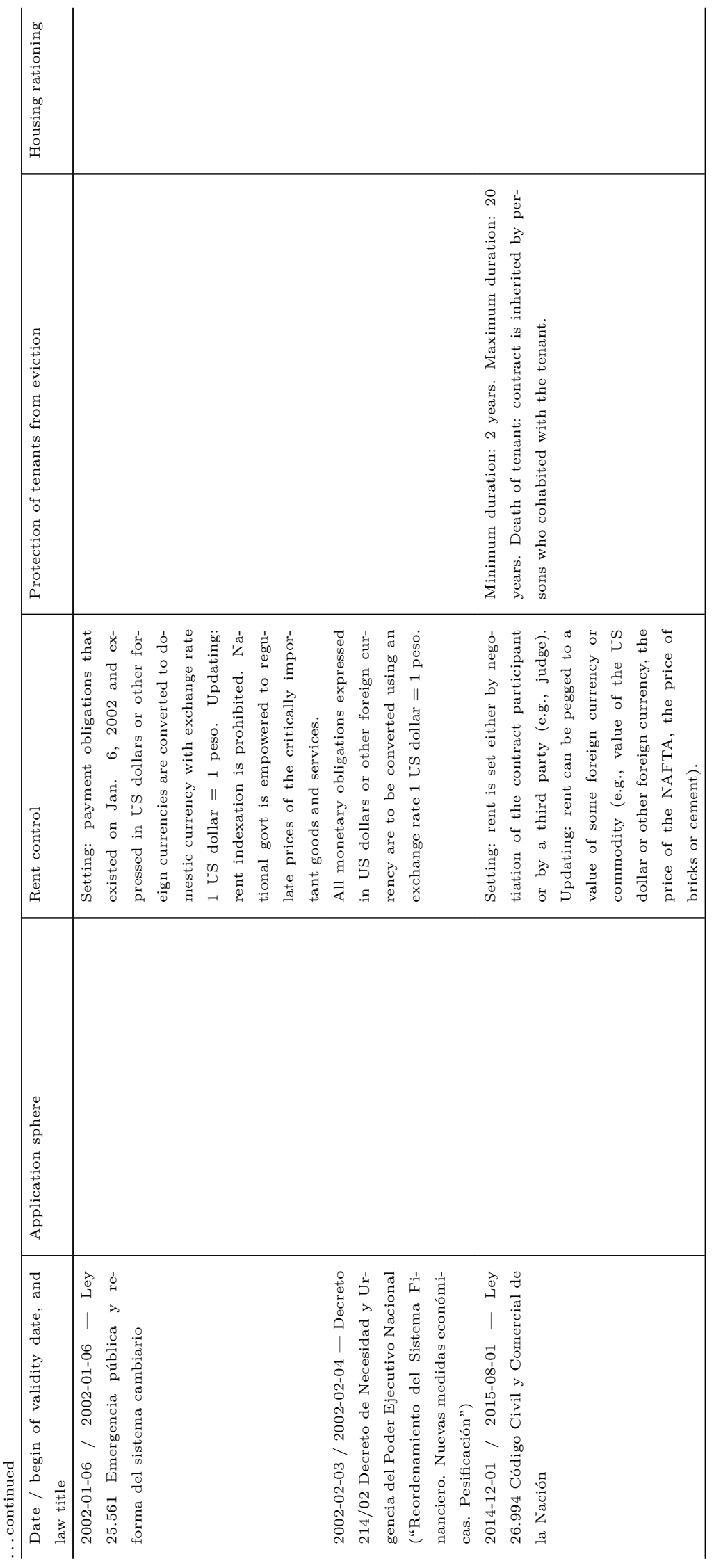


Table 5: Results of augmented Dickey-Fuller stationarity tests

\begin{tabular}{l|ccc}
\hline Variable & no drift no trend & with drift no trend & with drift and trend \\
\hline \multicolumn{4}{c}{ Levels } \\
\hline LRRent & 0.237 & 0.691 & 0.775 \\
RIRate & 0.010 & 0.060 & 0.195 \\
LPop & 0.979 & 0.010 & 0.875 \\
Lcgdppc & 0.984 & 0.777 & 0.020 \\
LPermits & 0.087 & 0.798 & 0.010 \\
\hline \multicolumn{4}{l}{} \\
\hline DLRRent & 0.010 & Differences & 0.024 \\
DRIRate & 0.010 & 0.010 & 0.010 \\
DLPop & 0.282 & 0.010 & 0.010 \\
DLcgdppc & 0.010 & 0.413 & 0.010 \\
DLPermits & 0.010 & 0.010 & 0.010 \\
\hline
\end{tabular}




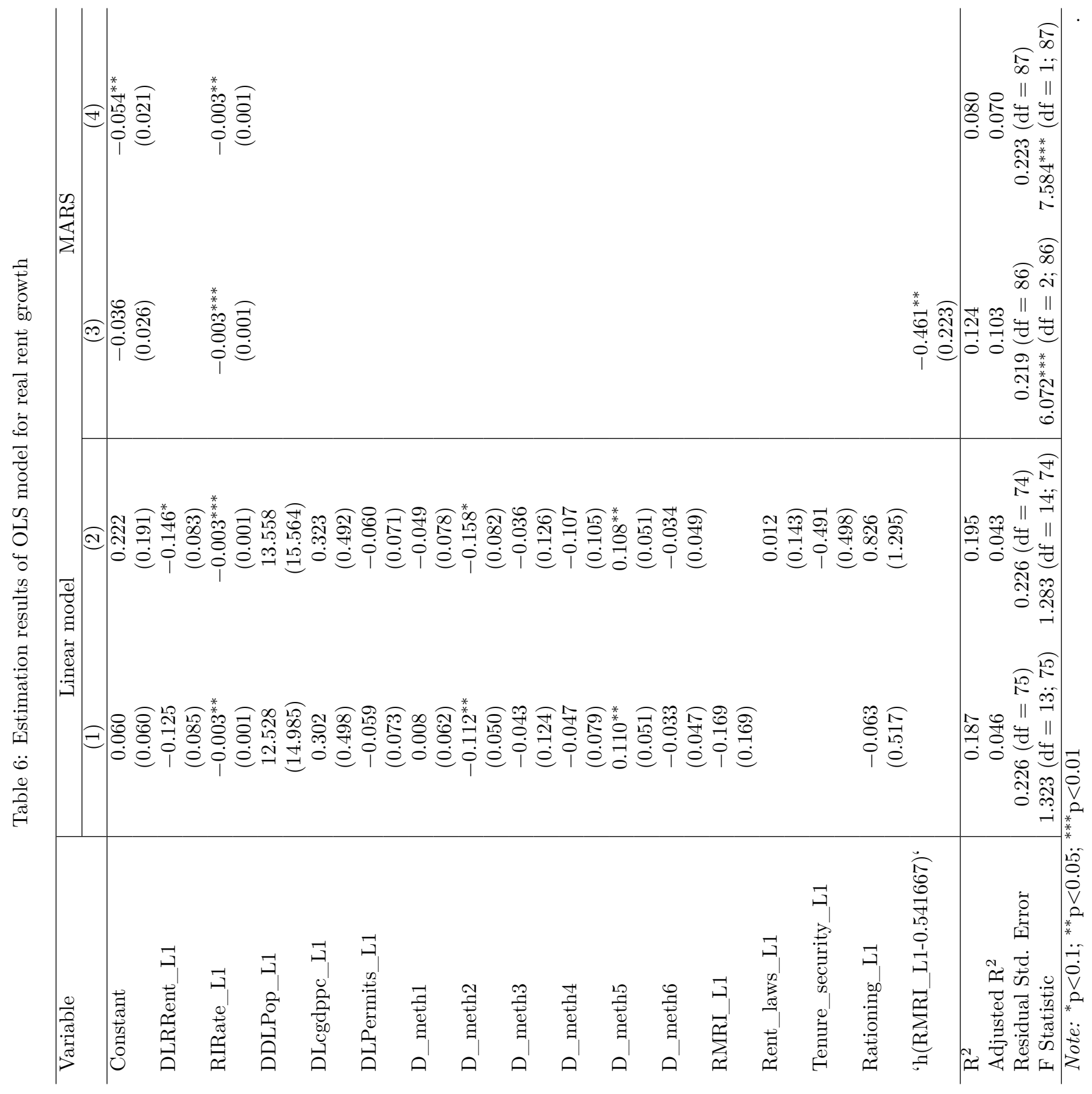


Figure 1: Tenant rate in Argentina, 1947-2018

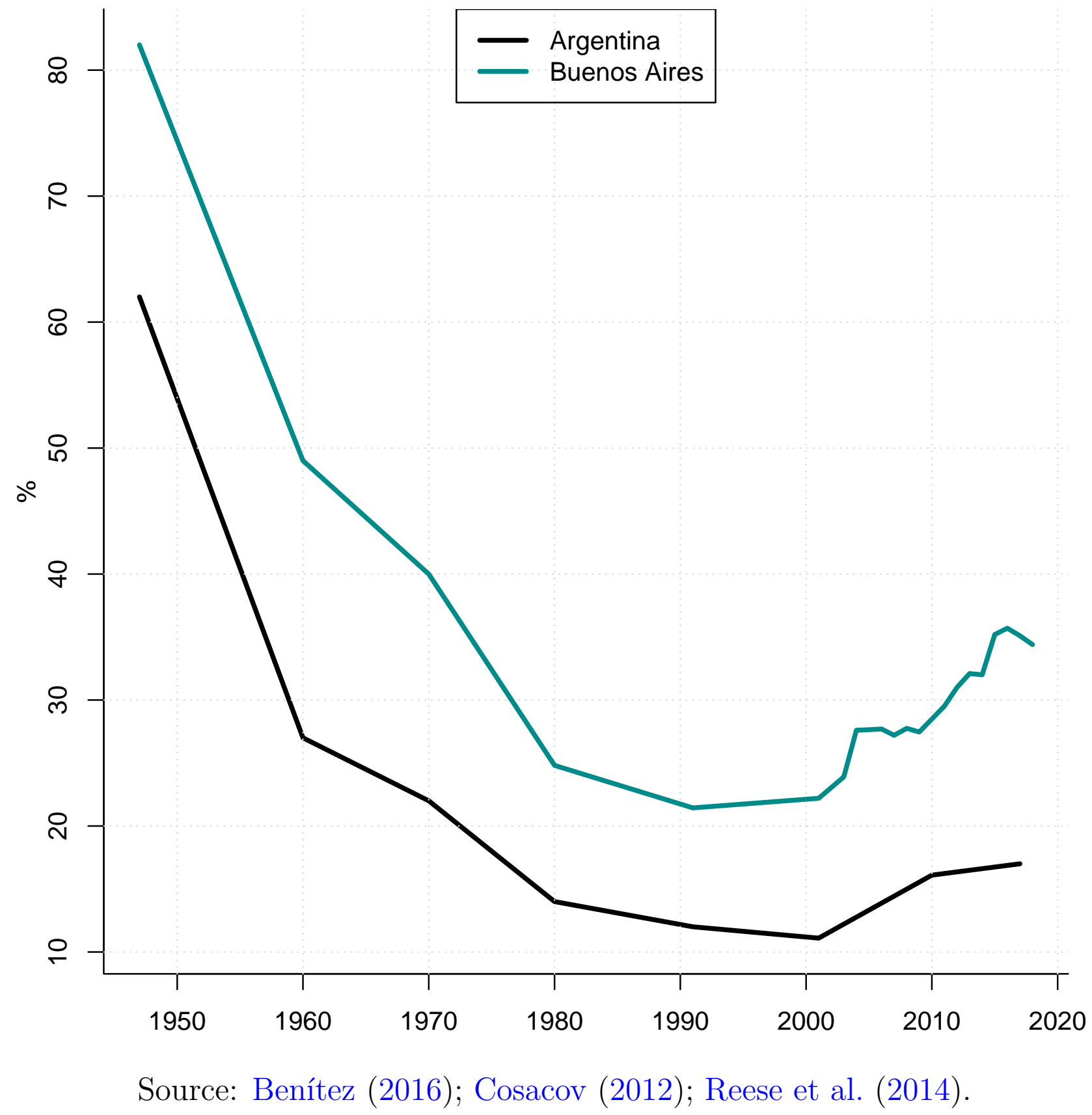


Figure 2: Dependent and control variables, 1910-2017
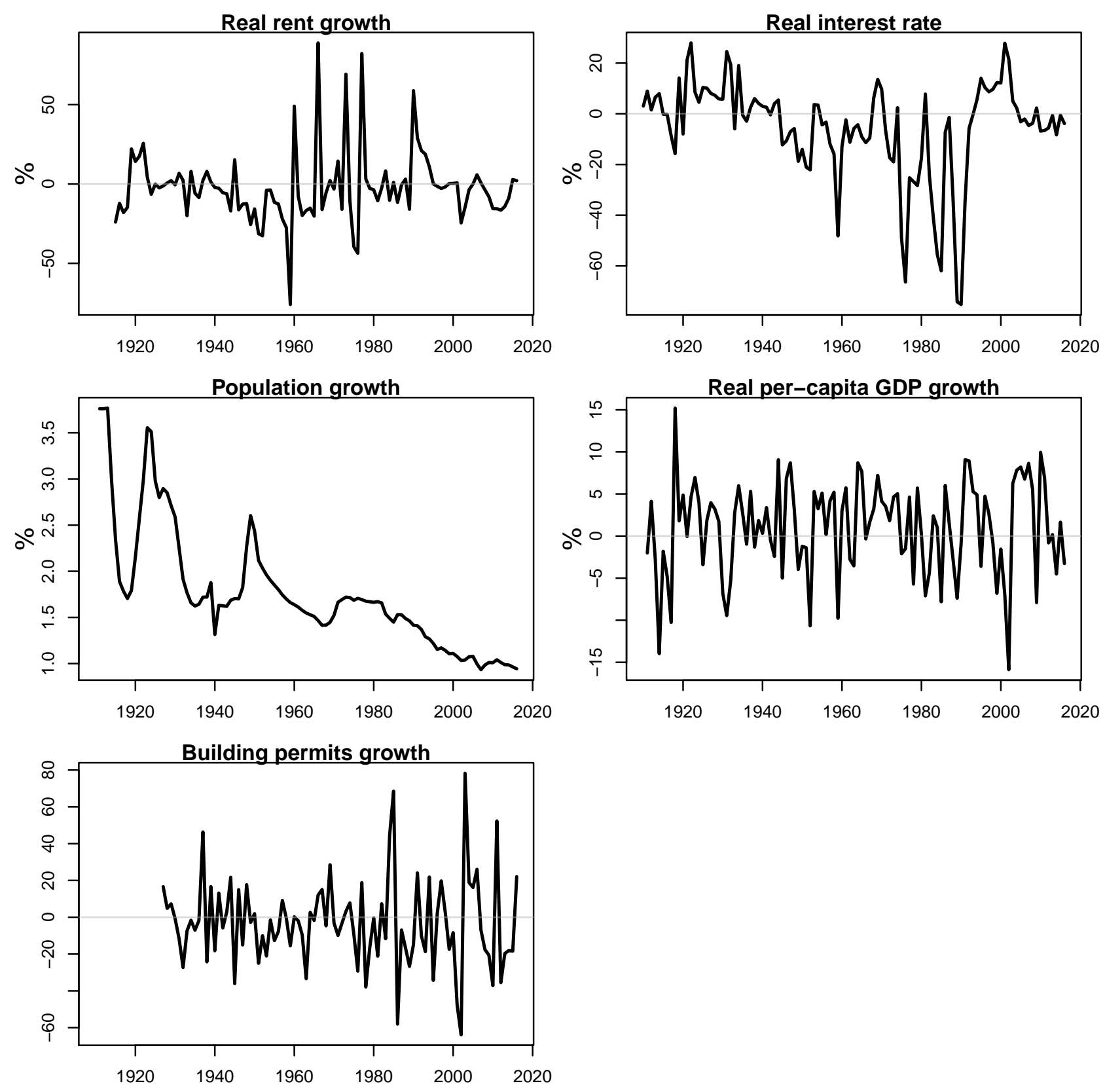
Figure 3: Rental market regulation indices in Argentina, 1910-2017
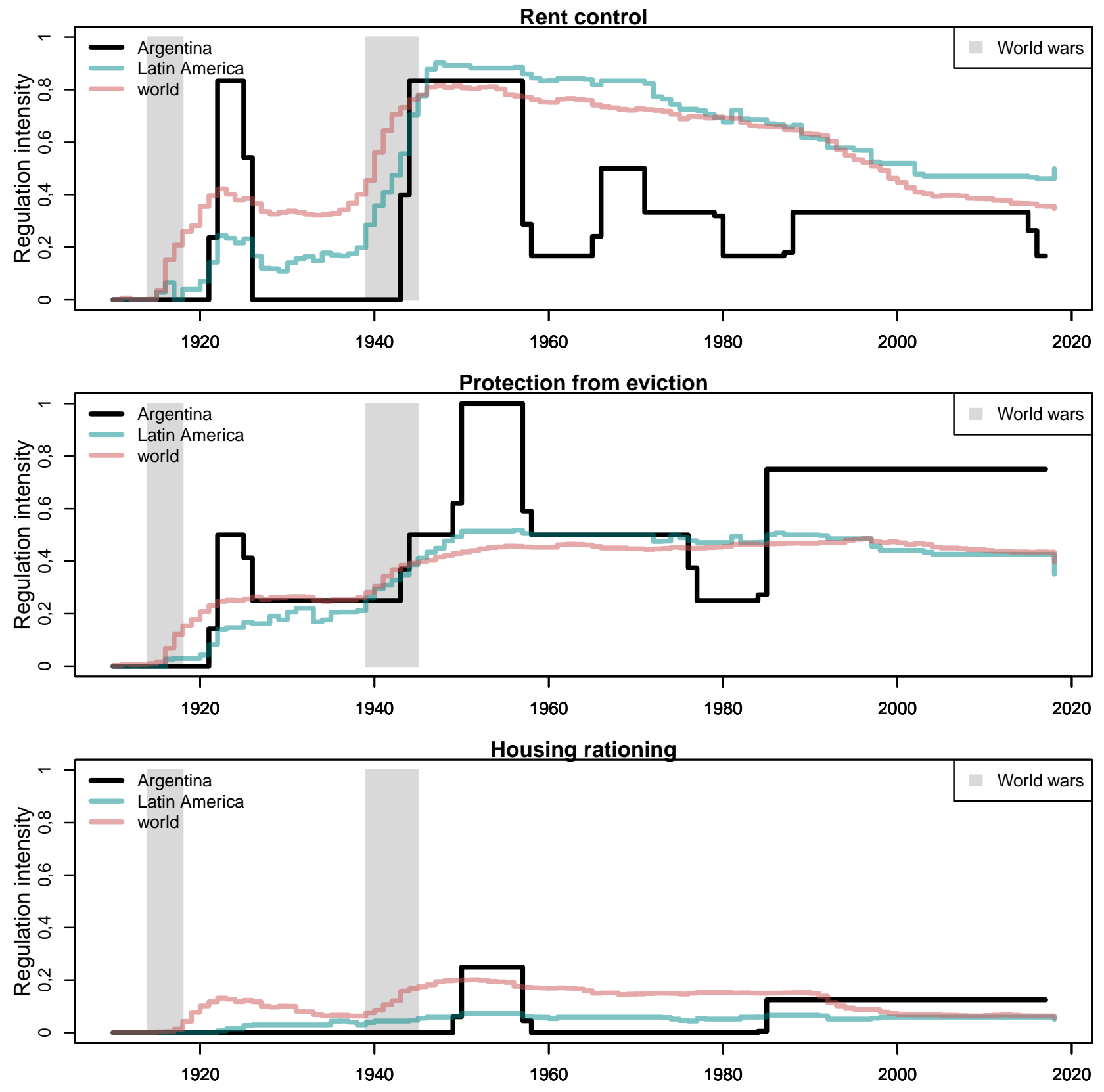
Figure 4: Regulation effects on real rent growth

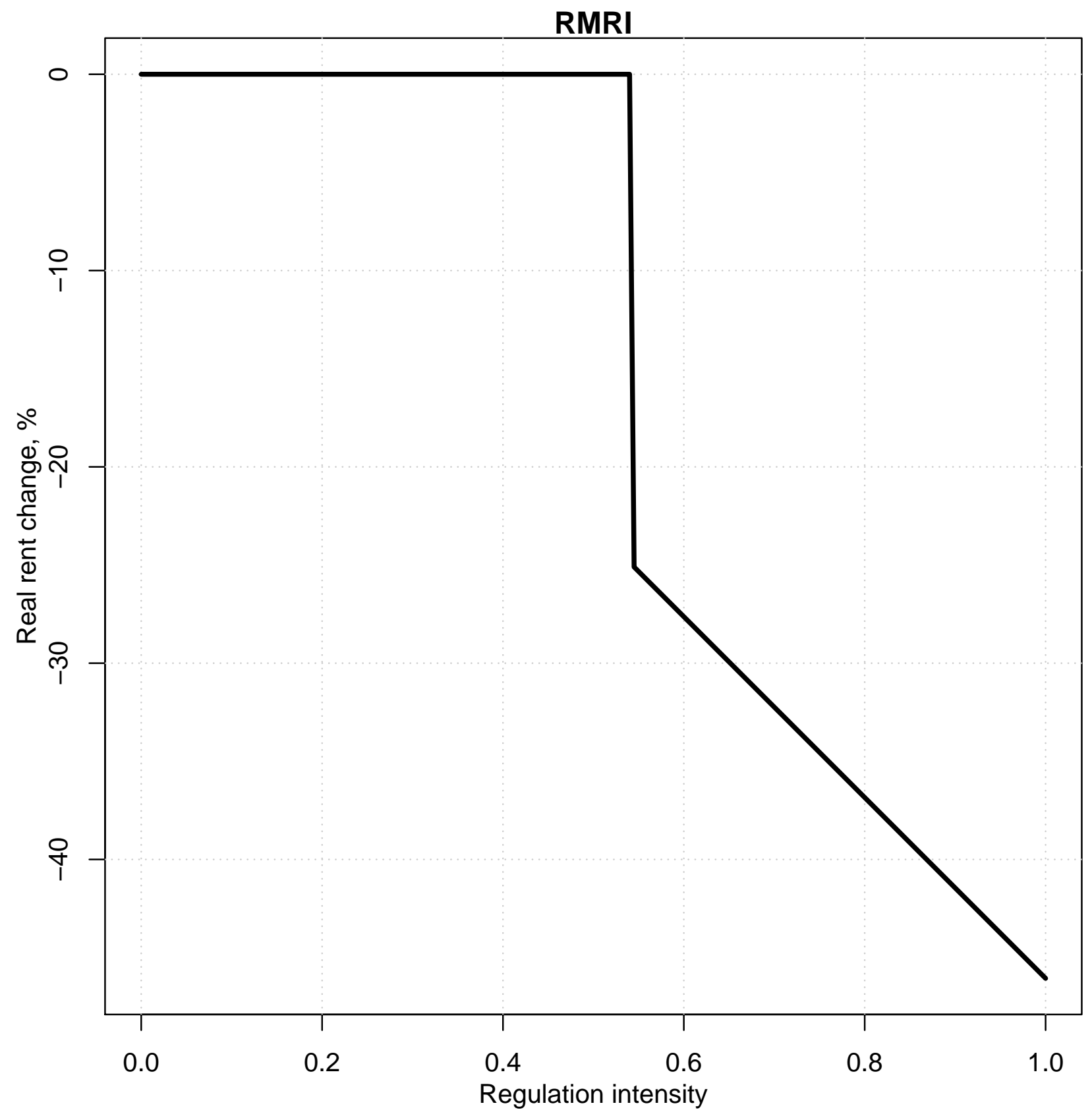

